DOI: $10.2478 / \mathrm{v} 10025-011-0010-8$

JOURNAL OF WATER

AND LAND DEVELOPMENT

J. Water Land Dev. No. 14, 2010: 115-133

\title{
Evaluation and verification of the WetSpa model based on selected rural catchments in Poland
}

\author{
Laura PORRETTA-BRANDYK ${ }^{1)}$, Jarostaw CHORMAŃSKI $I^{1)}$, \\ Stefan IGNAR ${ }^{1)}$, Tomasz OKRUSZKO ${ }^{1)}$, Andrzej BRANDYK ${ }^{2}$, \\ Tomasz SZYMCZAK ${ }^{3)}$, Katarzyna KRĘ̇̇ALEK ${ }^{3)}$
}

1) Warsaw University of Life Sciences, Department of Hydraulic Engineering and Environmental Restoration, Nowoursynowska Street 159, 02-776 Warsaw, Poland, laurap@levis.sggw.pl

2) Warsaw University of Life Sciences, Department of Environmental Improvement, Nowoursynowska Street 159, 02-776 Warsaw, Poland

${ }^{3)}$ Institute of Technology and Life Sciences, Department of Water Resources, Falenty, al. Hrabska 3, 05-090 Raszyn, Poland

\begin{abstract}
The paper presents results of calibration and verification of the WetSpa model, which enables the modelling of rainfall-runoff process based on mass and energy balance in the soil-plantatmosphere system in the catchment. It is a model with distributed parameters, using the structure of raster GIS model to determine the spatial diversity of the catchment environment. This enables simulation of runoff from the catchment, including: precipitation, evapotranspiration, interception of plant surface and soil cover, infiltration and capillary rise in soil and groundwater runoff. Simulated processes depend on the required non-distributed parameters, which were calibrated based on hydrometeorological data from the three rural catchments with different physical and geographical characteristics: Mławka, located in the Wkra basin in Central Poland and the rivers Kamienna and Sidra, which are tributaries of the upper Biebrza in north-eastern part of the country. Distributed catchment parameters were specified on the basis of digital soil maps, land use maps and digital elevation model using GIS techniques. Non-distributed model parameters were calibrated for the three catchments using automatic techniques based on the PEST algorithm. The obtained values of these parameters were scrutinized in order to analyse differences resulting from various characteristics of the study areas. The quality of the model was verified upon dependent and independent data. Appropriate quality measures, including Nash-Sutcliffe efficiency measure, were used to assess model quality. For two catchments (the Sidra and Kamienna) the model showed a satisfactory quality for modelling high flows, it was, however, not satisfactory for low flows. The values for the Mławka catchment justified the assessment of the model quality measurements as very good and good. The factors most affecting the process of river outflow formation were determined using the analysis of model sensitivity to relative changes in parameter values. It was found that the evaluation of the model quality depended largely on the quality of meteorological data and proper parameterization of the soil cover.
\end{abstract}

Key words: automatic calibration, distributed models, lowland rural catchment, rainfall-runoff process 


\section{INTRODUCTION}

The study was focussed on river runoff modelling in two catchments of rivers (the Sidra and Kamienna) which are tributaries to the Biebrza River in its upper reach, and in the upper Mławka River catchment. The outflow hydrographs for catchments were simulated using WetSpa computer software, which enabled rainfall - runoff modelling on a catchment's scale on the basis of mass and energy balance in soil - plant - atmosphere system. The model was developed by WANG et al. (1996) and adopted for flood prediction by de SMEDT et al. (2000), LiU et al. (2002). The model was successfully tested for flood hydrograph calculation in urbanized catchments (CHORMAŃSKI et al., 2008) and for lowland catchments with significant contribution of organic soils (CHORMAŃSKI and BATELAAN, 2010 submitted). WetSpa is a GIS based distributed hydrological model, partly physically based. Since physically based distributed hydrological modelling on catchment's scale requires many input layers and generates spatially distributed outputs, GIS is a very useful tool because of its efficiency in data storage, display and maintenance. Distributed hydrological models usually use GIS capabilities to estimate spatial parameters from topography and digital maps of soil type and land-use. The powerful GIS tools give new possibilities for hydrological research in understanding the fundamental physical processes underlying the hydrological cycle and for the solution of mathematical equations representing these processes. Apart from WetSpa, many hydrological models with a flood prediction component have been developed or updated to use DEM's, such as the SWAT model (ARNOLD et al., 1998), DWSM (BORAH et al., 2002), HYDROTEL (FORTIN et al., 2000), whereas models like SHE (ABBOTT, 1986) and TOPMODEL (BEVEN, 2001) were adapted to benefit from GIS data. These models are either partly or entirely coupled with GIS. On the other hand, inverse modelling is also upgraded by GIS techniques, which facilitates to calibrate model parameters by generating GIS layers of model sensitivities, relative parameter changes and other important factors evaluated in the calibration process.

The automated calibration and validation of the model was executed with the use of the PEST programme, and the assessment of those crucial processes was done by calculating errors of mathematical models performance. Then, the error values for modelled catchments were compared and the differences and similarities of global model parameters for these catchments were discussed. Error values showed that the model efficiency was good for high flows, but unsatisfactory for low flows in all catchments. The differences in the runoff between analysed catchments concerned climatic factors influencing evapotranspiration, and parameters determining ground water flow. 


\section{STUDY AREA}

The study catchments were selected in north-eastern Poland: the Sidra River closed by Harasimowicze gauge, and the Kamienna River, with Kamienna Stara gauge (Fig. 1). Both rivers are the main left side tributaries to the Biebrza River. Both catchments are located in the Upper Biebrza Basin - a river valley which is part of the Biebrza National Park - added to the RAMSAR Convention list as one of the most important wetlands worldwide. The valley formed as an ice marginal valley is relatively long $(40 \mathrm{~km})$ and narrow $(2-3 \mathrm{~km})$. It is filled with the thick deposits of peat (usually $2-5 \mathrm{~m}$ ) partly underlain by gyttja layer (1-4 m) (ŻUREK, 1994).

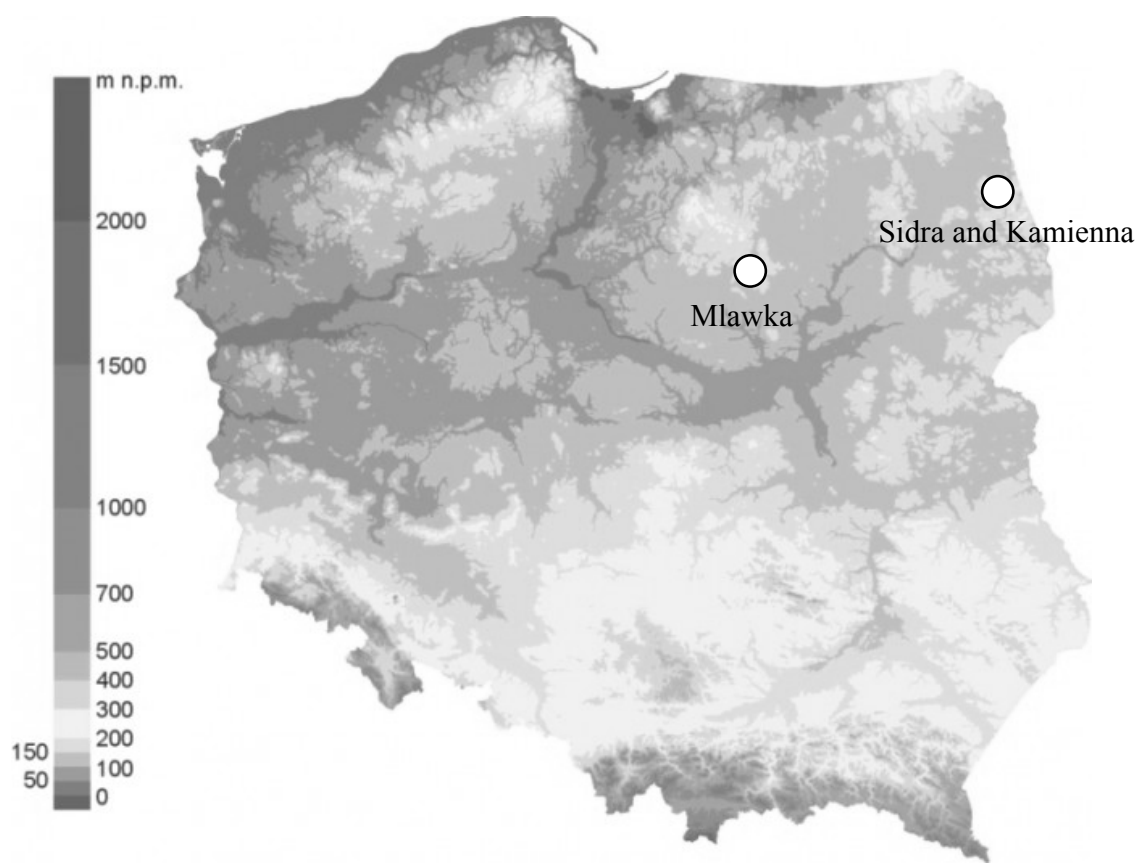

Fig. 1. Catchment of the Upper Mławka River and the catchments of the Kamienna and Sidra rivers

The Mławka (43.4 km long) is the first of the major left-bank tributaries of the Wkra River. Size of the whole catchment area is $675.5 \mathrm{~km}^{2}$, however, study area included headwater catchment - an area of $66.17 \mathrm{~km}^{2}$ located north of the town of Mława.

Upper catchment area is characterised by a high hydraulic conductivity (up to $10^{-3} \mathrm{~m} \cdot \mathrm{s}^{-1}$ ) determined by lithology of moraine deposits. This facilitates rapid infiltration of rainwater into the depth, but a substantial thickness of the aeration zone hampers and slows down the process of supplying the first aquifer. 
Basic physiographic characteristics of selected catchments are given in Table 1. The catchment area of the Kamienna River is five times smaller than the catchment of the Sidra River, the total length of the Kamienna is two times smaller, while the slope is approximately two times higher than in the Sidra catchment. The Mławka River catchment area is comparable with the Kamienna River catchment. The Mławka catchment area is slightly (by 18\%) larger than the former but has a shorter main stream (by about 36\%) and lower slopes.

Table 1. Physiographic characteristics of Kamienna, Sidra and Mławka catchments

\begin{tabular}{lcccc}
\hline Catchment & Area, $\mathrm{km}^{2}$ & River length, $\mathrm{km}$ & Main chanel slope, \%o \\
\hline Kamienna & 56 & 17.9 & 3.00 \\
Sidra & 264 & 32.8 & 1.46 \\
Mławka & 66 & 11.5 & 1.75 \\
\hline
\end{tabular}

Both catchments of the Biebrza tributaries are used for agriculture in about $70 \%$ of their areas. However, the catchment of the Kamienna, compared with the Sidra catchment, is characterised by a smaller surface of forests and shrubs and a relatively high share of grasslands with typically high retention capabilities (Tab. 2). The share of arable grounds in the catchment of the Mławka River is smaller compared to the two other catchments (by 10-14\%). Forested area is similar there to the catchment of the Sidra, however, the proportion of grasslands is more than eleven times higher. The Mławka catchment area has the biggest share of urbanized areas, more than two times higher than that in the Kamienna catchment and seven times higher than in the Sidra catchment. Hydrological regime of the catchments is described in Table 3.

Table 2. Land use structure of the Kamienna, Sidra and Mławka catchments

\begin{tabular}{l|c|c|c|c}
\hline \multirow{2}{*}{ Catchment } & \multicolumn{4}{c}{ Land use, \% } \\
\cline { 2 - 5 } & arable grounds & forests and shrubs & grasslands & $\begin{array}{c}\text { urbanized and } \\
\text { communication areas }\end{array}$ \\
\hline Kamienna & 71.2 & 13.7 & 14.1 & 1.0 \\
Sidra & 73.8 & 24.9 & 1.0 & 0.3 \\
Mławka & 63.8 & 22.6 & 11.5 & 2.1 \\
\hline
\end{tabular}

The catchment of the Kamienna has a higher value of $H H q$ than the Sidra catchment although the latter is nearly five times larger than the former. The reason for this untypical situation is the slope of the Kamienna catchment which is in general two times higher than in the Sidra. Therefore floods accumulate faster and achieve higher peak discharges there. 
Table 3. Characteristic discharges and unit runoff values estimated for the period 1973-1987 for the Kamienna and Sidra catchments and for the period of 1977-1986 for the Mławka River catchment

\begin{tabular}{l|r|c|c|c|c|c|c|c}
\hline \multirow{2}{*}{ Catchment } & $H H Q$ & $M M Q$ & $M E Q$ & $L L Q$ & $H H q$ & $M M q$ & $M E q$ & $L L q$ \\
\cline { 2 - 9 } & \multicolumn{6}{c}{$\mathrm{m}^{3} \cdot \mathrm{s}^{-1}$} \\
\hline Kamienna & 28.5 & 0.5 & 0.2 & 0.0 & 508.9 & 8.9 & 3.0 & 0.0 \\
Sidra & 26.0 & 1.5 & 1.1 & 0.2 & 98.5 & 5.6 & 4.2 & 0.7 \\
Mławka & 5.1 & 0.4 & 0.4 & 0.1 & 77.2 & 6.2 & 5.4 & 1.4 \\
\hline
\end{tabular}

Explanation: $H H Q$ - the highest of the high observed discharges, $M M Q$ - the mean of the mean observed discharges, $M E Q$ - the median of the mean observed discharges, $L L Q$ - the lowest of the low observed discharges, $H H q$ - the highest of the high observed unit runoff, $M M q$ - the mean of the mean observed unit runoff, $M E q$ - the median of the mean observed unit runoff, $L L q$ - the lowest of the low observed unit runoff.

\section{METHODS}

A model selected for this work was the GIS-based distributed watershed model - WetSpa (developed for simulation of rainfall-runoff processes in the catchment scale). In an actual version the model was developed as an ArcGIS 9.3.1 or ArcGIS 10 module. For each grid cell, vegetation, root, transmission and saturated zones are considered in the vertical direction (Fig. 2). The hydrological processes parameterized in the model are: precipitation, interception, depression storage, surface runoff, infiltration, evapotranspiration, percolation, interflow and groundwater flow. The total water balance for a raster cell is composed of the water balance for the vegetated and bare soil, water and impervious parts of each cell. This allows for representing within-cell heterogeneity of the land cover. A mixture of physical and empirical relationships is used to describe the hydrological proc-

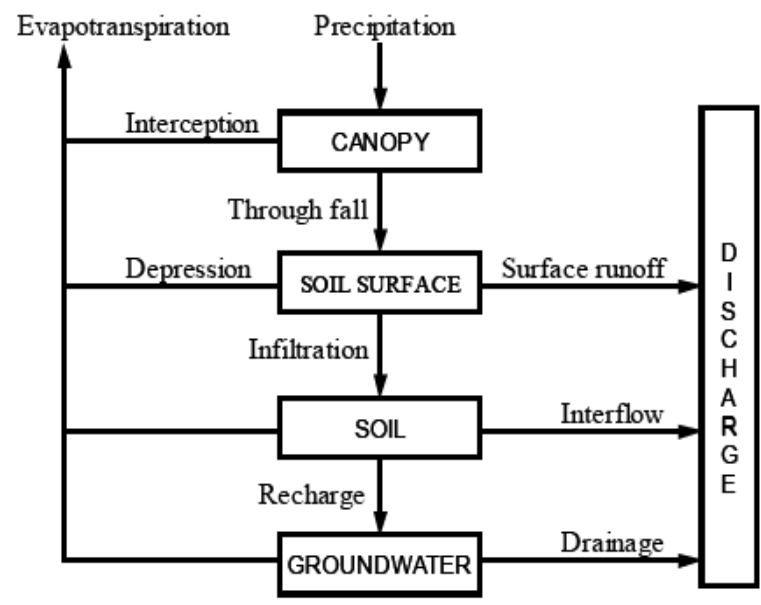

Fig. 2. The structure of WetSpa at a grid cell level 
esses in the model. Interception reduces the precipitation to net precipitation, which on the ground is separated into rainfall excess and infiltration. Rainfall excess is calculated using a moisture-related modified rational method with a potential runoff coefficient depending on land cover, soil type, slope, rainfall intensity, and preceding moisture content of the soil. The calculated rainfall excess fills the depression storage at the initial stage and runs off the land surface simultaneously as overland flow (LINSLEY et al., 1982).

The infiltrated part of the rainfall remains as soil moisture in the root zone, moves laterally as interflow or percolates as groundwater recharge depending on the moisture content of the soil. Both percolation and interflow are assumed to be gravity driven in the model. Percolation out of the root zone is determined by the hydraulic conductivity, which is dependent on the moisture content as a function of the soil pore size distribution index:

$$
R=K(\theta)=K_{s}\left[\frac{\theta-\theta_{r}}{\theta_{r}-\theta_{s}}\right]^{\frac{2+3 B}{B}}
$$

where:

$K(\theta)$ - unsaturated hydraulic conductivity, $\mathrm{mm} \cdot \mathrm{h}^{-1}$;

$\theta \quad$ - soil moisture content, $\mathrm{mm} \cdot \mathrm{h}^{-1}$;

$\theta_{r} \quad$ - residual moisture content, $\mathrm{m}^{3} \cdot \mathrm{m}^{-3}$;

$\theta_{s} \quad-$ soil porosity, $\mathrm{m}^{3} \cdot \mathrm{m}^{-3}$;

$B \quad-$ cell pore size distribution index.

Interflow is assumed to occur in the root zone after percolation and becomes significant only if the soil moisture is higher than the field capacity. Darcy's law and kinematic approximation are used to estimate the amount of interflow generated from each cell, in a function of hydraulic conductivity, moisture content, slope, and root depth. Interflow is assumed to contribute to the nearest channel or ditch flows (LIU et al., 2002):

$$
F=\frac{C_{f} D S_{o} K(\theta)}{W}
$$

where:

$D$ - the root depth, L;

$S_{o}$ - the surface slope, $\mathrm{L} \cdot \mathrm{L}^{-1}$;

$W$ - cell width, L;

$C_{f}$ - scaling parameter (a function of land use) to consider river density and effects of organic matter on the horizontal hydraulic conductivity in the top soil layer. 
In this case study, as only one measuring station was available, this method was not used. Due to limited knowledge about the bedrock, a non-linear relationship was used to estimate groundwater flow in each subcatchment. The total discharge at the outlet is the sum of the overland flow, interflow and groundwater flow from all the grid cells.

The actual evapotranspiration from soil and plants was calculated for each grid cell using the relationship developed by THORNTHWAITE (1955) and as a function of potential evapotranspiration, vegetation stage, and moisture content in the cell. Out of the vegetation period, potential evapotranspiration was assumed to be zero.

Runoff from different cells in the watershed was driven to the watershed outlet depending on flow velocity and wave coefficient by using the diffusive wave approximation method. An approximate solution proposed by DE SMEDT et al. (2000) in the form of an instantaneous unit hydrograph (IUH) was used in the model, relating the discharge at the end of a flow path to the available runoff at the start of the flow path:

$$
u(t)=\frac{1}{\sigma \sqrt{2 \pi t^{3} / t_{0}^{3}}} \exp \left[\frac{\left(t_{0}-t\right)^{2}}{4 \sigma^{2} t / t_{0}}\right]
$$

where:

$u(t)$ - the unit response function, $\mathrm{T}^{-1}$;

$t_{0} \quad$ - the average travel time to the outlet along the flow path, $\mathrm{T}$;

$\sigma \quad$ - the standard deviation of the flow time.

Parameters $t_{0}$ and $\sigma$ are spatially distributed, and can be obtained by integration along the topographically determined flow paths as a function of flow celerity and dispersion. These parameters are physically based and can be estimated by using standard GIS functions.

The total flow hydrograph at a basin outlet can be obtained by a convolution integral of the flow response from all grid cells.

$$
Q(t)=\int_{A} \int_{0}^{t} Q_{e}(\tau) U(t-\tau) d \tau d A
$$

where

$Q(t)$ - the outlet flow hydrograph, $\mathrm{L}^{3} \cdot \mathrm{T}^{-1}$;

$Q_{\mathrm{e}}$ - the excess precipitation in a grid cell, $\mathrm{L} \cdot \mathrm{T}^{-1}$;

$\tau$ - the time delay, $\mathrm{T}$,

$A$ - drainage area of the watershed, $\mathrm{L}^{2}$. 
Although the spatial variability of land use, soil and topographic properties within a watershed were considered in the model, the groundwater response was modelled on sub-catchment scale. The simple concept of a linear reservoir was used to estimate groundwater discharge, while a non-linear reservoir method was optional in the model (WITTENBERG and SIVAPALAN, 1999). The groundwater outflow was added to the generated runoff to produce the total stream flow at the subwatershed outlet. Time-dependent inputs of the model were precipitation and potential evapotranspiration. Model parameters such as interception and depression storage capacity, potential runoff coefficient, overland roughness coefficient, root depth, soil property parameters, average travel time to the outlet, dispersion coefficient, etc., were determined for each grid cell using lookup tables and a highresolution DEM, soil type and land-use maps (Fig. 3). The main outputs of the model were river flow hydrographs, which can be defined for any location along the channel network, and spatially distributed hydrological characteristics, such as soil moisture, infiltration rates, groundwater recharge, surface water retention, runoff, etc.

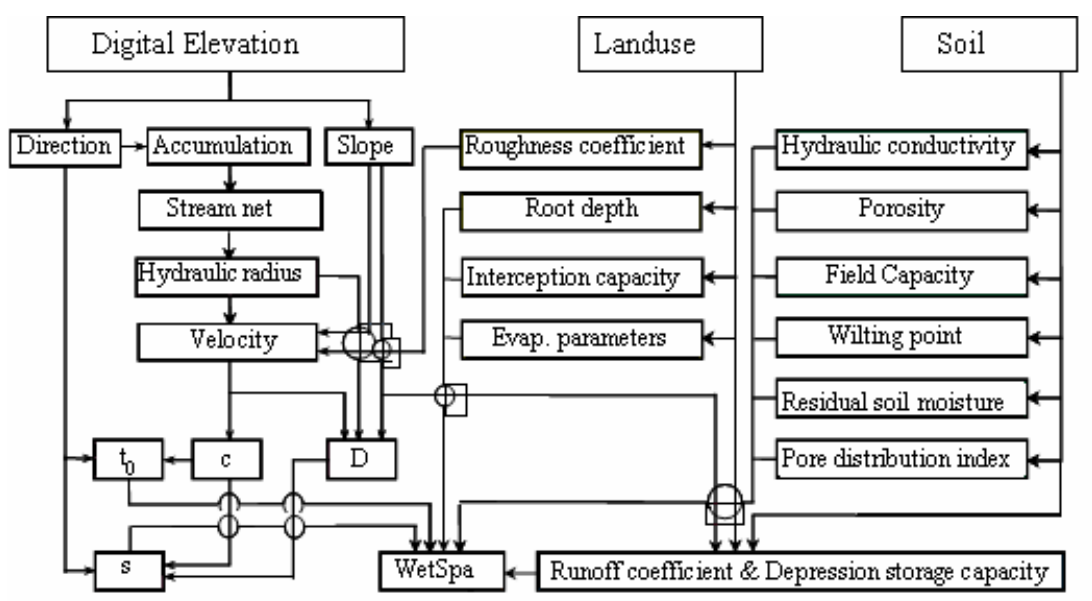

Fig. 3. Parameterization of local parameters in the WetSpa model

\section{MODEL CALIBRATION AND EVALUATION}

During the calibration 11 global parameters were used by the model. The rough calibration was performed automatically with PEST (DOHERTY et al., 1994), a model-independent non-linear parameter estimator, which was implemented in WetSpa. Then, a fine-tuning calibration was performed manually. The calibration processes consisted of running the model as many times as it was necessary to adjust model parameters within their predetermined range until the discrepancies be- 
tween model outputs and a complementary set of flow observations were reduced. The model was evaluated by graphical comparisons of simulated and observed hydrographs and assessment of goodness of fit between them by five statistical evaluation criteria CR1, CR2, CR3, CR4, and CR5:

\section{CR1 - Model bias}

Model bias can be expressed as the relative mean difference between predicted and observed stream flows for a sufficiently large simulation sample, reflecting the ability of reproducing water balance, and being perhaps the most important criterion for comparison whether a model is working well in practice. Error CR1 is the model bias, $Q s_{i}$ and $Q o_{i}$ are the simulated and observed stream flows at time step $i$ $\left(\mathrm{m}^{3} \cdot \mathrm{s}^{-1}\right)$, and $N$ is the number of time steps over the simulation period, $\bar{Q} O$ is the arithmetical mean of the observed discharges. Model bias measures the systematic under- or overestimation of a set of predictions. A lower CR1 value indicates a better fit, and the value 0.0 represents the perfect simulation of observed flow volume. The criterion is given by the equation:

$$
C R 1=\frac{\sum_{i=1}^{N}\left(Q s_{i}-Q o_{i}\right)}{\sum_{i=1}^{N} Q o_{i}}
$$

\section{CR2 - Model confidence}

Model confidence is an important criterion in assessment of continuous model simulation, and can be expressed by the determination coefficient. CR2 represents the proportion of the variance in the observed discharges that is explained by the simulated discharges. It varies between 0 and 1 , with a value close to 1 indicating a high level of model confidence. It is given by the equation:

$$
C R 2=\frac{\sum_{i=1}^{N}\left(Q s_{i}-\bar{Q} o\right)}{\sum_{i=1}^{N}\left(Q o_{i}-\bar{Q} o\right)^{2}}
$$

\section{CR3 - Nash-Sutcliffe efficiency}

The Nash-Sutcliffe coefficient (NASH and SUTCLIFFE, 1970) describes how well the stream flows are simulated by the model. This efficiency criterion is commonly used for model evaluation because it involves standardization of the residual variance and its expected value does not change with the length of the record or the scale of runoff. The Nash-Sutcliffe efficiency is used for evaluating the ability of 
reproducing the time evolution of stream flows. The CR3 value can range from a negative value to 1 , with 1 indicating a perfect fit between the simulated and observed hydrographs. CR3 below zero indicates that average measured stream flow would have been as good a predictor as the modelled stream flow. A perfect model prediction has CR3 score equal to 1. It has the form of:

$$
C R 3=\frac{\sum_{i=1}^{N}\left(Q o_{i}-\bar{Q} o\right)^{2}-\sum_{i=1}^{N}\left(Q o_{i}-Q s_{i}\right)^{2}}{\sum_{i=1}^{N}\left(Q o_{i}-\bar{Q} o\right)^{2}}
$$

\section{CR4 - Logarithm version of Nash-Sutcliffe efficiency for low flow evaluation}

CR4 is a logarithm Nash-Sutcliffe efficiency for evaluating the ability of reproducing the time evolution of low flows and $\varepsilon$ is an arbitrary chosen small value introduced to avoid problems with nil observed or simulated discharges. A perfect value of CR4 is 1 .

$$
C R 4=1-\frac{\sum_{i=1}^{N}\left[\ln \left(Q s_{i}+\varepsilon\right)-\ln \left(Q o_{i}+\varepsilon\right)\right]^{2}}{\sum_{i=1}^{N}\left[\ln \left(Q o_{i}+\varepsilon\right)-\ln (Q o+\varepsilon)\right]^{2}}
$$

\section{CR5 Adapted version of Nash-Sutcliffe efficiency for high flow evaluation}

CR5 is an adapted version of Nash-Sutcliffe criterion for evaluating the ability of reproducing the time evolution of high flows. A perfect value of CR5 is 1. To evaluate the goodness of the model performance during calibration and validation periods, the intervals listed in Table 4 were adopted (ANDERSEN et al., 2001). These criteria are not of the fail/pass type, but evaluate the performance in the categories from excellent to very poor.

$$
C R 5=1-\frac{\sum_{i=1}^{N}\left(Q o_{i}+\bar{Q}_{o}\right)\left(Q s_{i}-Q o_{i}\right)^{2}}{\sum_{i=1}^{N}\left(Q o_{i}+\bar{Q}_{o}\right)\left(Q o_{i}-\bar{Q}_{o}\right)^{2}}
$$

After model calibration and verification, the comparison of global model parameter values for Sidra and Kamienna catchments was performed in order to discover differences and similarities in the formation of runoff process in lowland catchments. Model efficiency for low flows, which, in small catchments usually 
reached unsatisfactory values, was estimated. The sensitivity calculation of calibrated model parameters was also performed.

Table 4. Model performance categories to indicate the goodness level

\begin{tabular}{c|c|c}
\hline Range of C1 & Range of C2-C5 & Model quality category \\
\hline$<0.05$ & $>0.85$ & excellent \\
$0.05-0.10$ & $0.65-0.85$ & very good \\
$0.10-0.20$ & $0.50-0.65$ & good \\
$0.20-0.40$ & $0.20-0.50$ & satisfactory/poor \\
$>0.40$ & $<0.20$ & unsatisfactory/very poor \\
\hline
\end{tabular}

\section{INPUT HYDROMETEOROLOGICAL DATA}

The input discharge data set originated from historical hydrological data for the period 1976-1986 in gauges of Harasimowicze (the Sidra River), Kamienna Stara (the Kamienna River) and Mławka village (the Mławka River). The input meteorological data for the catchment in the Upper Biebrza Basin included daily precipitation and mean daily temperature from Różanystok station located at a distance of $15 \mathrm{~km}$ from the computational river cross-sections, and potential evapotranspiration from the Biebrza Meteorological Station located in the Middle Biebrza Basin at a distance of $30 \mathrm{~km}$ from computational cross-sections: Harasimowicze and Kamienna Stara. Meteorological services for both stations in Różanystok and in Biebrza were provided by the Institute of Meteorology and Water Management (IMGW). Potential evapotranspiration for the vegetation period (1 April-30 September) was calculated according to the Penman formula modified for Polish condition by ROGUSKI et al. (1988). The input meteorological data set for Mławka was taken from meteorological station and 5 precipitation stations supported by the Institute of Technology and Life Sciences (former Institute for Land Reclamation and Grassland Farming). All these stations were located in the catchment area. The latter meteorological station was active till the year 1995, there is, however, a meteorological station belonging to the IMGW approximately $6 \mathrm{~km}$ from the cross-section Mławka.

The correctness of performed modelling was evaluated on the basis of daily discharges for the analysed gauging cross-sections. The range of data was divided into two five-year periods: the data for 1977-1981 were used for model calibration while the data for 1982-1986 served for model validation. Simulations were performed for a daily time step. 


\section{RESULTS}

The values of sensitivity analysis are presented in Table 5 . The sensitivities of model parameters were most significant for K_ep K_ss, K_g and Ki. So, the model results will be significantly influenced by the ratio of the vertical to the horizontal soil conductivity (determined by $\mathrm{Ki}$ value), and by the recession of ground water outflow (K_g value). Discharge hydrographs at the analysed cross - sections will be also shaped vitally by the applied relative soil moisture values (K_ss ) and potential evapotranspiration rates, adjusted by K_ep parameter. Figures 4, 5 and 6 show daily discharge hydrographs for one exemplary year chosen from the calibration period. Figures 7, 8 and 9 represent daily discharges for two chosen years of the validation period.

Table 5. Calculated parameter sensitivities

\begin{tabular}{ccccc}
\hline Parameter & Kamienna & Sidra & Mławka \\
\hline Ki & 1.71 & $1.58 \mathrm{E}-02$ & 1.98 \\
Kg & 0.85 & 1.09 & 0.73 \\
K_ss & 3.82 & 0.69 & 1.12 \\
K_ep & 4.17 & 4.54 & 1.08 \\
G0 & $4.6 \mathrm{E}-04$ & $9.12 \mathrm{E}-04$ & $7.58 \mathrm{E}-04$ \\
G_max & $3.7 \mathrm{E}-05$ & $3.25 \mathrm{E}-05$ & $3.53 \mathrm{E}-05$ \\
T0 & 0 & 0 & 0 \\
K_snow & 0 & 0 & 0 \\
K_rain & 0 & 0 & 0 \\
K_run & $6.21 \mathrm{E}-03$ & $9.82 \mathrm{E}-04$ & $1.13 \mathrm{E}-03$ \\
P_max & 0.45 & 0.25 & 1.00 \\
\hline
\end{tabular}

Explenation: $\mathrm{Ki}$ - interflow scaling parameter, $\mathrm{Kg}$ - the groundwater recession coefficient, $\mathrm{K}$ ss - relative soil moisture, K_ep - plant coefficient for estimating actual potential evapotranspiration, G0 - initial groundwater storage (m), G_max - maximum groundwater storage (m), T0 - base temperature for estimating snow melt $\left({ }^{\circ} \mathrm{C}\right)$, K_snow - degree-day coefficient for calculating snow melt $\left(\mathrm{mm} \cdot \mathrm{mm}^{-1} \cdot{ }^{\circ} \mathrm{C}^{-1} \cdot \mathrm{day}^{-1}\right), \mathrm{K}$ rain - rainfall degree-day coefficient $\left(\mathrm{mm} \cdot \mathrm{mm}^{-1} \cdot{ }^{\circ} \mathrm{C}^{-1} \cdot \mathrm{day}^{-1}\right), \mathrm{K}_{-}$run - an exponent reflecting the effect of rainfall intensity on the actual runoff coefficient when the rainfall intensity is very small, $P_{-} \max$ - threshold rainfall intensity $\left(\mathrm{mm} \cdot \mathrm{day}^{-1}\right)$.

The comparison of the calculated and observed discharge hydrographs for the calibration period confirmed the proper execution of calibration process. However, the comparison made for the validation data, revealed some problems with accurate simulation of low flows (baseflow) for the whole year (summer and winter period altogether) for the Sidra and Kamienna rivers. This was most likely caused by errors in soil maps, which did not present a real soil type distribution in the catchment. Therefore, local model parameters of infiltration and ground water flow were incorrect. The other source of error involved most likely the distance to rain gauging stations and the number of those stations that affected representation of spatial variability of precipitation. 


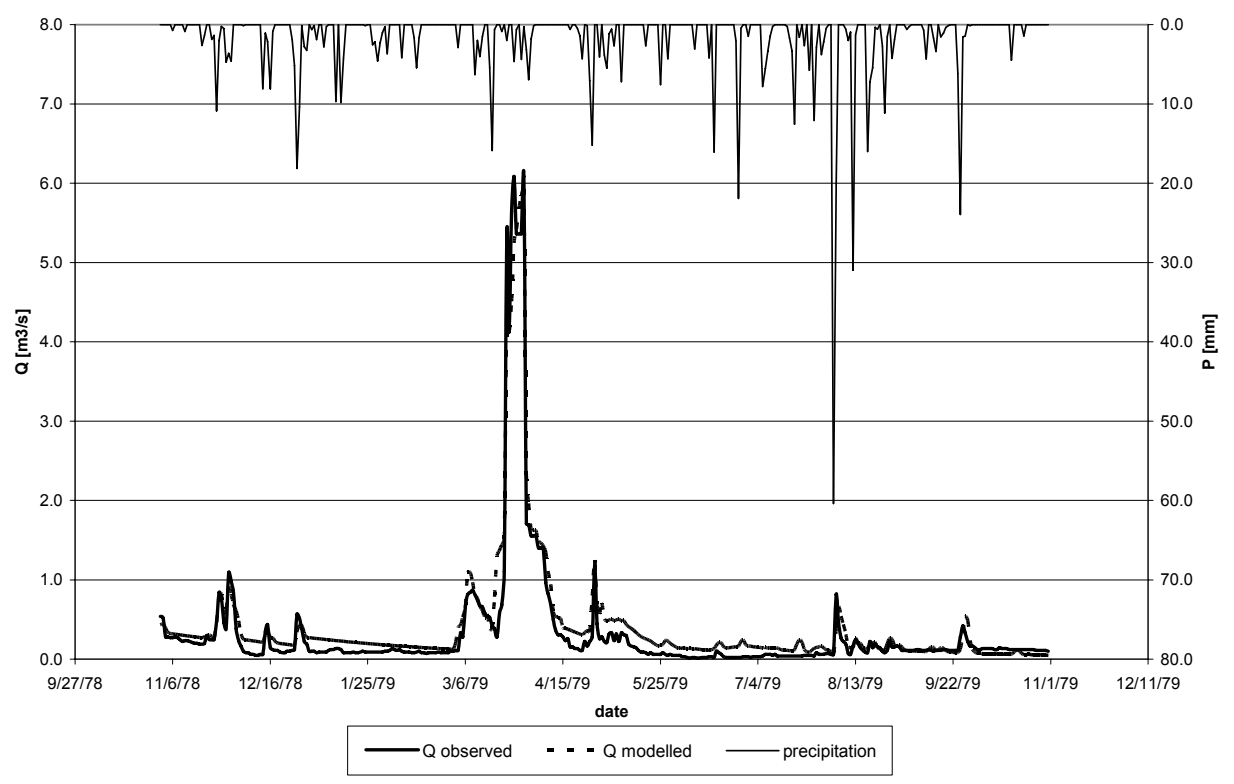

Fig. 4. Calculated and observed daily discharge hydrographs for the Kamienna River, calibration period 1 XI 1978-31 X 1979

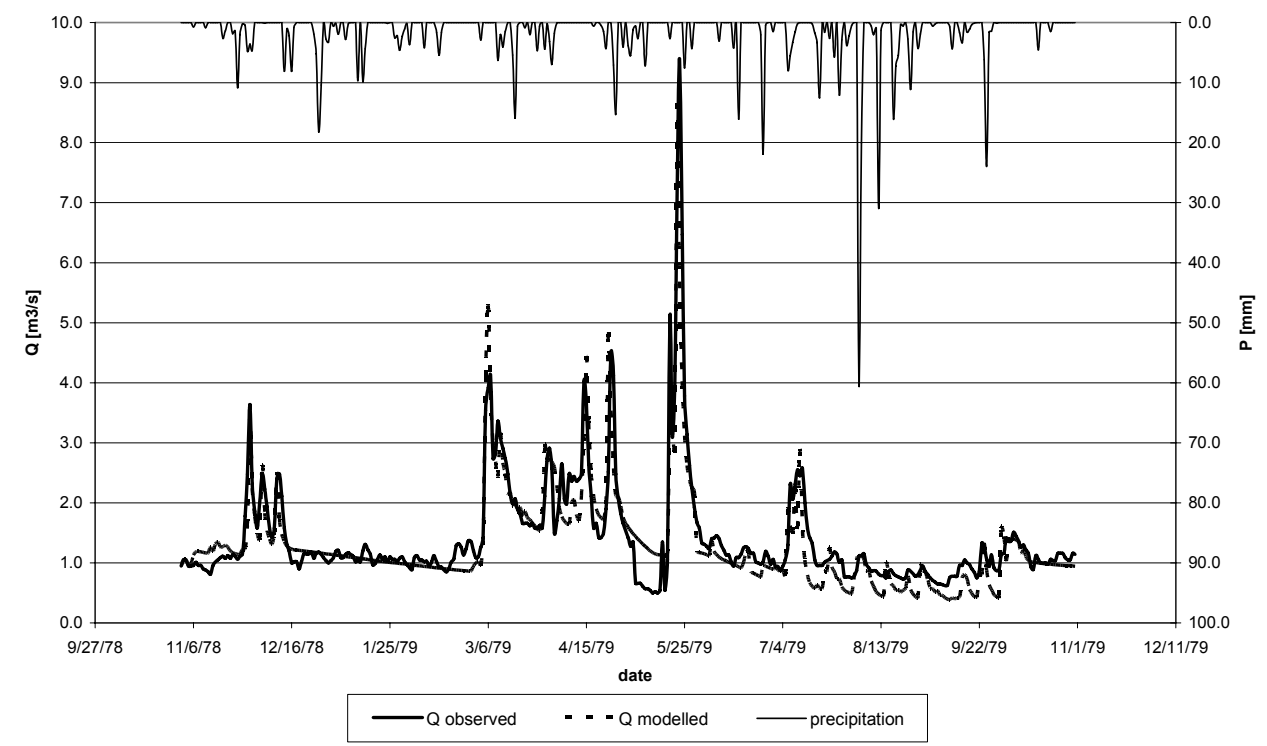

Fig. 5. Calculated and observed daily discharge hydrographs for the Sidra River, calibration period 1 XI 1978-31 X 1979 


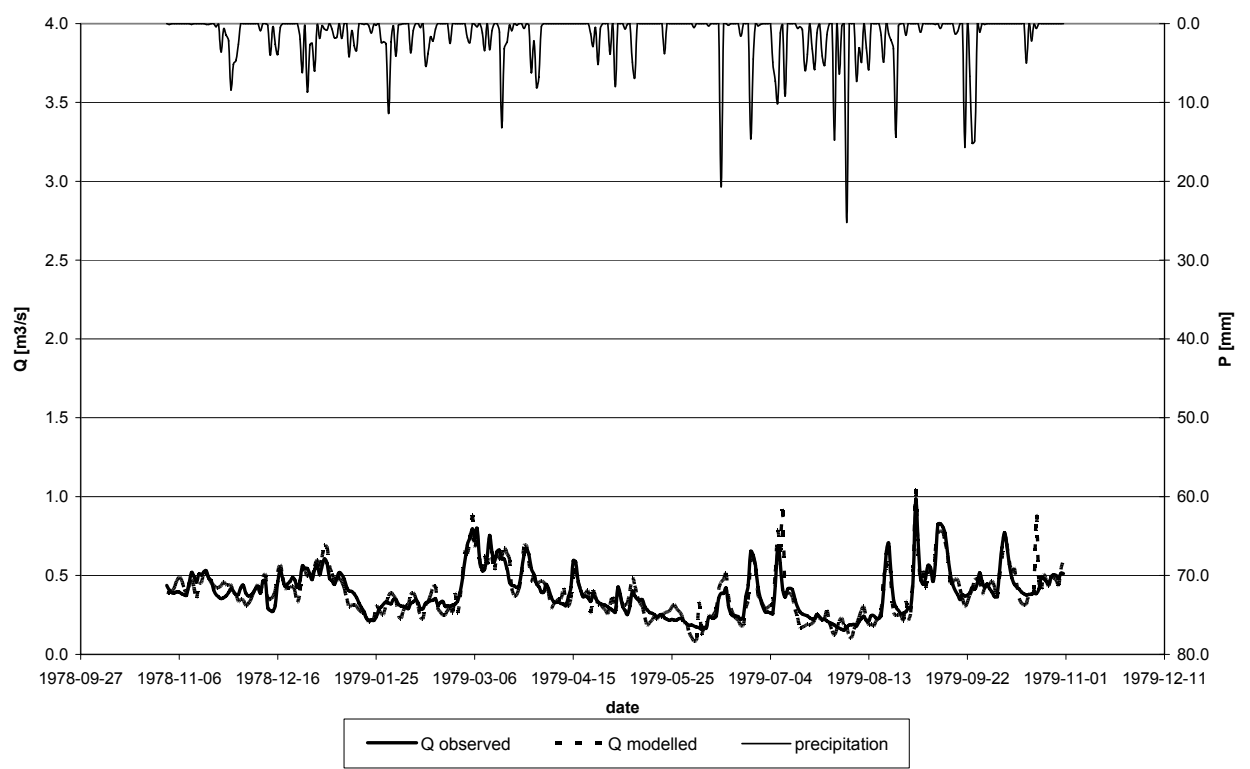

Fig. 6. Calculated and observed daily discharge hydrographs for the Mławka River, calibration period 1 XI 1978-31 X 1979

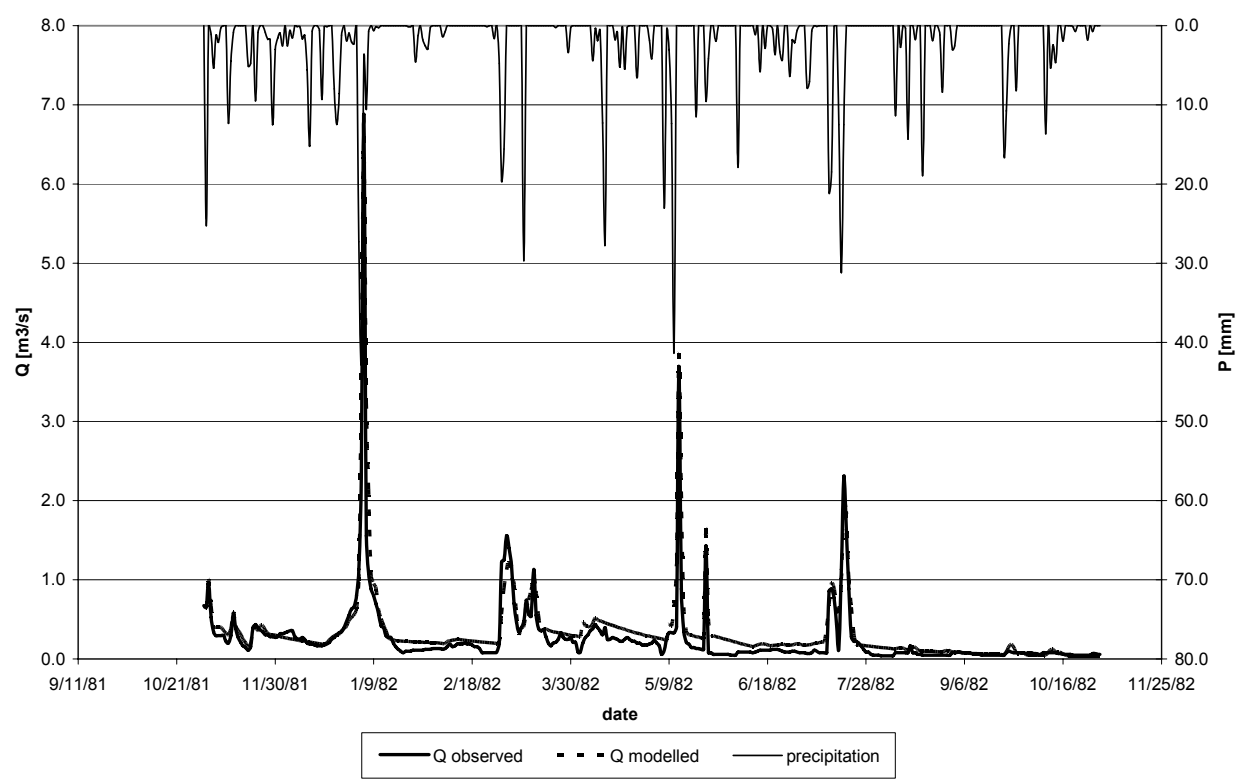

Fig. 7. Calculated and observed daily discharge hydrographs for the Kamienna River, validation period 1 XI 1981-31 X 1982 


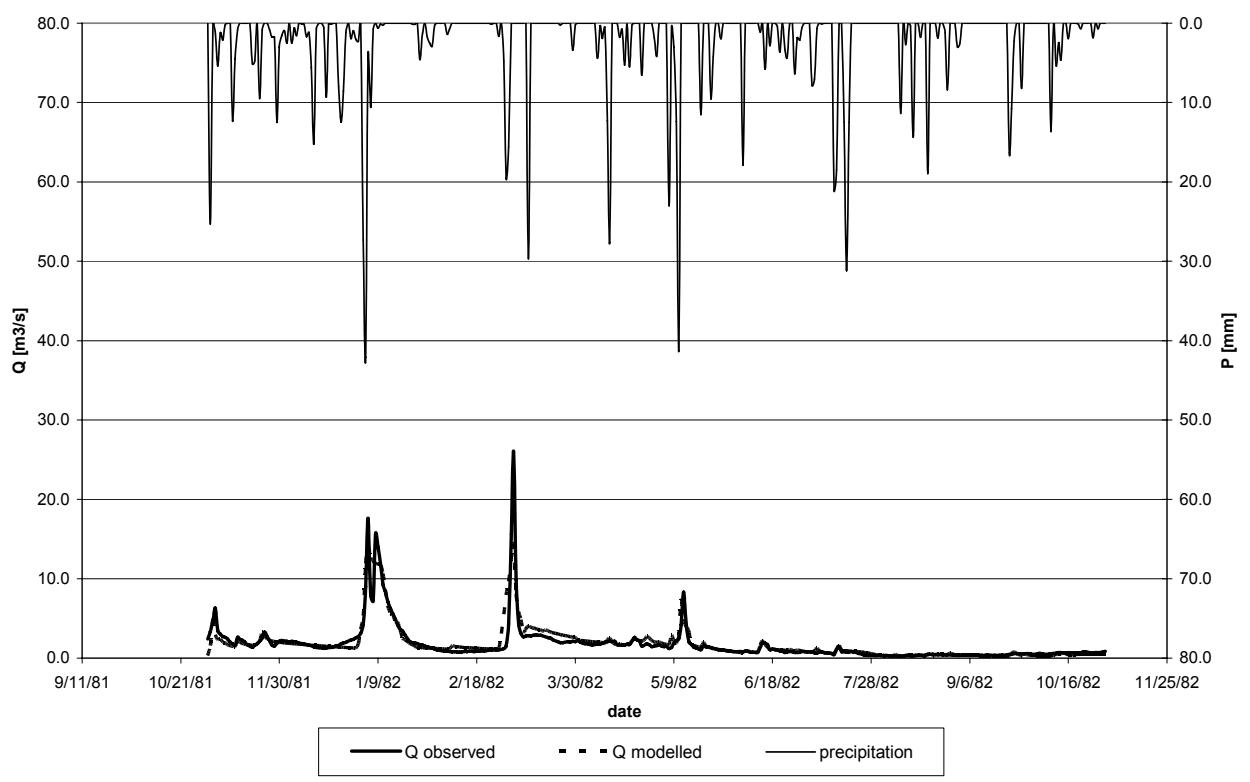

Fig. 8. Calculated and observed daily discharge hydrographs for the Sidra River, validation period 01 XI 1981-31 X 1982

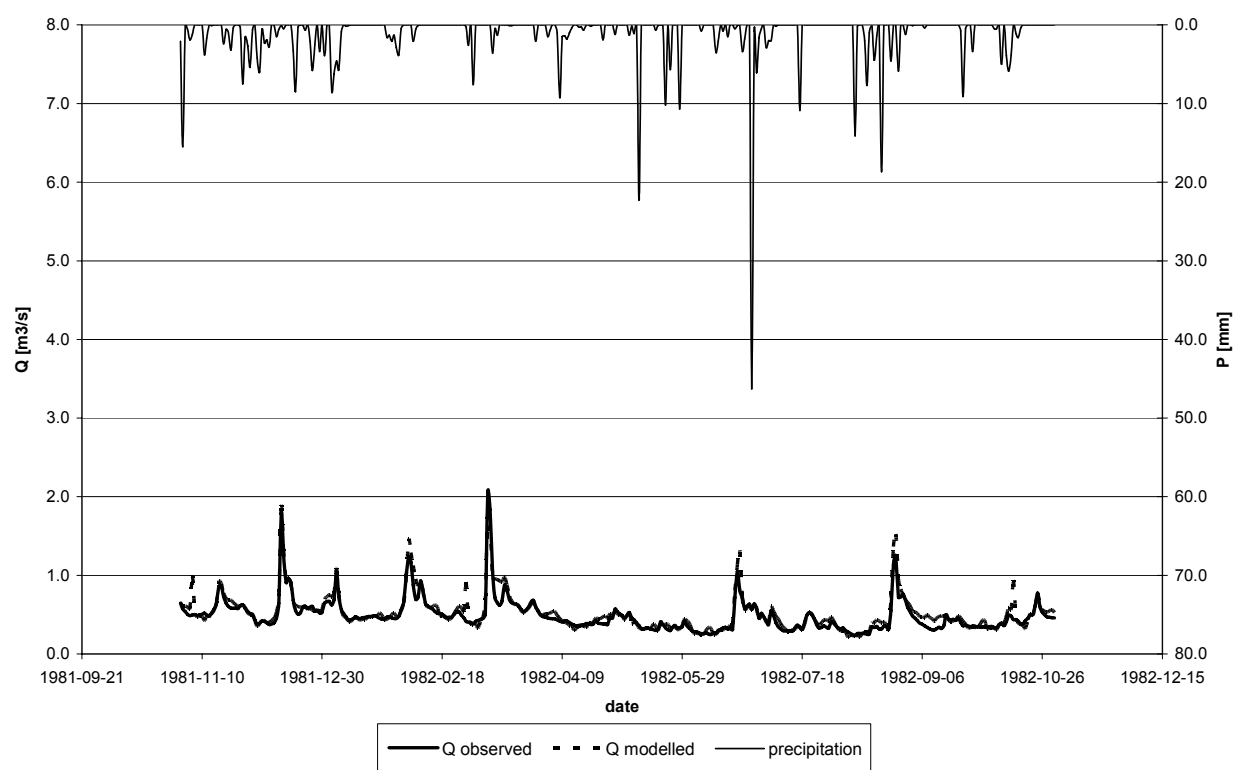

Fig. 9. Calculated and observed daily discharge hydrographs for the Mławka River, validation period 01 XI 1981-31 X 1982 
The goodness of fit was estimated by the statistical evaluation criteria errors C1-C5 (tab. 6).

Table 6. Evaluation criteria $\mathrm{C} 1-\mathrm{C} 5$ and $R^{2}$ for the calibration and verification of the WetSpa model

\begin{tabular}{|c|c|c|c|c|c|c|}
\hline Parameter & $\mathrm{C} 1$ & $\mathrm{C} 2$ & $\mathrm{C} 3$ & $\mathrm{C} 4$ & $\mathrm{C} 5$ & $R^{2}$ \\
\hline \multicolumn{7}{|c|}{ Kamienna Stara gauge, the Kamienna River } \\
\hline Calibration & 0.08 & 0.70 & 0.72 & 0.31 & 0.83 & 0.80 \\
\hline Verification & 0.05 & 0.73 & 0.69 & 0.35 & 0.81 & 0.80 \\
\hline Optimum & 0 & 1 & 1 & 1 & 1 & 1 \\
\hline \multicolumn{7}{|c|}{ Harasimowicze gauge, the Sidra River } \\
\hline Calibration & 0.06 & 0.71 & 0.69 & 0.20 & 0.78 & 0.72 \\
\hline Verification & 0.03 & 0.69 & 0.66 & 0.34 & 0.81 & 0.69 \\
\hline Optimum & 0 & 1 & 1 & 1 & 1 & 1 \\
\hline \multicolumn{7}{|c|}{ Mławka gauge, the Mławka River } \\
\hline Calibration & 0.01 & 0.81 & 0.75 & 0.58 & 0.86 & 0.83 \\
\hline Verification & 0.01 & 0.78 & 0.74 & 0.55 & 0.82 & 0.82 \\
\hline Optimum & 0 & 1 & 1 & 1 & 1 & 1 \\
\hline
\end{tabular}

The values of C1-C5 errors were similar for all three catchments, but the best - for the Mławka River catchment. The values of C1 and C2, C3, C5 were found to be close to the optimum and showed very good model performance. The values of $\mathrm{C} 4$ were low for all catchments and not coherent with the optimum. Similar C1-C5 values were obtained for the WetSpa model of the whole Upper Basin up to the closing cross-section at Sztabin, constructed in a lower resolution and including both analysed subcatchments: Sidra and Kamienna (CHORMAŃSKI and BATELAAN, 2010). For the WetSpa model of the whole Upper Basin appropriate high values of $\mathrm{C} 1, \mathrm{C} 2, \mathrm{C} 3$ and C5 were reached while the value of C4 was poor as for the Sidra and Kamienna catchments. The quality of the model was estimated based on C1C5 calculated either for the whole validation or calibration period. No separate values were calculated for the summer or winter periods, but it seems from the comparison of hydrographs, that better accuracy for low flows was reached for the summer periods, while the accuracy of high and medium flows reproduction was comparable for the whole year. Low $\mathrm{C} 4$ values indicate a poor reproduction of low flows for the Sidra and Kamienna catchments. There was, however, a good quality of low flow modelling for the Mławka.

\section{CONCLUSIONS}

1. The WetSpa model applied to runoff modelling for three analysed rural catchments was sensitive to: the ratio of the vertical to horizontal soil hydraulic conductivity, ground water recession, relative soil moisture and potential 
evapotranspiration. For every catchment, the model was sensitive to the same parameters.

2. The ratio of the vertical to horizontal soil conductivity was most significant for the Mławka, than for the Kamienna, and less significant for the Sidra. Ground water recession was significant for the runoff process in an opposite order: most significant for the Sidra, less significant for the Kamienna and least significant for the Mławka. The same order was valid for potential evapotranspiration. Relative soil moisture had the highest impact on discharge results for the Kamienna, a high impact for the Mławka and the lowest for the Sidra.

3. The comparison of modelled and observed hydrographs confirmed proper calibration of global model parameters, there were, however, still some errors in baseflow simulation. They were most probably associated with poor soil type mapping in the catchment and with problems of sufficient representation of rainfall variability.

4. Calculated $\mathrm{C} 1$ values classify the model for the Mławka as excellent, and very good for the Kamienna and the Sidra. Range of C2-C5 errors provided the estimate of the Mławka model to be good or very good, and satisfactory or good for the Sidra and Kamienna.

5. The desired quality of calibration of rainfall - runoff model parameters for small lowland catchments can be obtained in an automated manner followed by manual refinement of parameter values. Optimization by the PEST programme should be performed for a rough estimate of parameter values, then a trial and error calibration procedure should follow.

6. Calibration enabled to determine such values of parameters describing runoff process, that led to the satisfactory reproduction of time evolution of flows in the studied lowland catchments.

7. Moving from large-scale models to local ones didn't successfully solve the quality problem of low flow simulation.

\section{REFERENCES}

1. Aвbott M.B., Bathurst J.C., Cunge J.A., O’Connell P.E., Rasmussen J., 1986. An introduction to the European Hydrological System, SHE. 1: History and philosophy of a physically based, distributed modelling system. Journal of Hydrology, 87: 45-59.

2. ANDERSEN J., REFSGAARD J., JENSEN K.H., 2001. Distributed hydrological modelling of the Senegal river basin; model construction and validation. Journal of Hydrology, 247: 200-214.

3. ARnold J.G., SRinivasan R., Muttiah R.S., Wiliams J.R., 1998. Large area hydrologic modeling and assessment. Part I. Model development. Journal of American Water Resources Association 34(1): 73-89.

4. BEVEN K., 2001: Rainfall-runoff modelling. The Primer. Hoboken, John Wiley and Sons: 1-360.

5. BORAH D.K., XIA R., BERA M., 2002. DWSM - A dynamic watershed simulation model. In: Mathematical models of small watershed hydrology and applications. Ed. V.P. Singh, D.K. Freyert. Water Resources Publications, LLC, Highlands Ranch, Colorado, USA: 113-166. 
6. Chormański J., Van de Voorde T., De Roeck T., Batelaan O., Canters F., 2008. Improving distributed runoff prediction in urbanized catchments with remote sensing based estimates of impervious surface cover. Sensors 8: 910-932.

7. ChORMAŃSKi J., BATElAAN O., 2010. Application of the WetSpa distributed hydrological model for catchment with significant contribution of organic soil. Upper Biebrza case study. Annals of Warsaw University of Life Sciences, SGGW Land Reclamation (submitted).

8. Doherty J., BrebBer L., Whyte P., 1994. PEST: model independent parameter estimation. Watermark Computing Trademarks, Australian.

9. Fortin J.P., Turcotte R., Massicotte S., Moussa R., Fitzback J., Villeneuve J.P., 2001. A distributed watershed model compatible with remote sensing and GIS data. I: Description of the model. Journal of Hydrological Engineering, 6(2): 91-99.

10. Liu Y.B., Gebremeskel S., De Smedt F., Pfister L., 2002. Flood prediction with the WetSpa model on a catchment scale. In: Flood Defence. Eds. B.S. Wu, Z.Y. Wang, G.Q. Wang, G.H. Huang, H.W. Fang, J.C. Huang. New York Ltd., Science Press.

11. Linsley R.K.J., Kohler M.A., PAulhus J.L.H., 1982. Hydrology for engineers. 3rd Ed. New York, McGraw-Hill: 1-237.

12. NASH J., SUTCLIFFE J., 1970. River of forecasting through conceptual models. Part 1a: Discussion of principles. Journal of Hydrology 10: 282-290.

13. OSTROwSKI J., 1994. Model regionalny małej zlewni "Moremaz-1". (A regional model of the small catchment „, Moremaz -1”). Materiały Badawcze IMGW Ser. Hydrologia i Oceanologia, 17.

14. RoguSKi W., SARNACKA S., DRUPKA S., 1988. Instrukcja wyznaczania potrzeb i niedoborów wodnych roślin i użytków zielonych. (Guidelines for predicting crop and pasture water needs). Materiały Instruktażowe 66. Falenty, IMUZ: 1-90.

15. De Smedt F., LiU Y.B., Gebremeskel S., 2000. Hydrologic modeling on a catchment scale using GIS and remote sensed land use information. In: Risk analysis II. Ed. C.A. Brebbia. Southampton, Boston, WTI press: 295-304.

16. Thornthwaite C.W., Mather J.R., 1955. The water balance. Publications in Climatology vol. 8 no. 1. Centerton, New Jersey, C.W. Thornthwaite Associates: 1-86.

17. Wang Z.M., BatelaAn O., De Smedt F., 1996. A distributed model for water and energy transfer between soil, plants and atmosphere (WetSpa). Physics and Chemistry of the Earth, 21(3): 189-193.

18. Wittenberg H., SivAPAlan M., 1999. Watershed groundwater balance estimation using streamflow recession analysis and baseflow separation. Journal of Hydrology, 219: 20-33.

19. ŻUREK S., 1994: Geomorphology of the Biebrza valley. In: Towards protection and sustainable use of the Biebrza Wetlands: Exchange and integration of research results for the benefit of a Polish Dutch Join Research Plan. Report 3A. Eds. H. Okruszko, M.J. Wassen. Utrecht: 15-48.

\section{STRESZCZENIE}

\section{Ocena i weryfikacja modelu WetSpa w warunkach wybranych zlewni rolniczych w Polsce}

Słowa kluczowe: modele o parametrach rozłożonych, proces opad-odpływ, automatyczna kalibracja, nizinne zlewnie rolnicze

W pracy przedstawiono wyniki kalibracji i weryfikacji modelu WetSpa, który umożliwia modelowanie typu opad-odpływ na podstawie bilansu masy i energii w systemie gleba-roślina-atmosfera w obszarze zlewni rzecznej. Jest to model o parametrach rozłożonych, wykorzystujący strukturę rastrowego modelu GIS do 
określenia przestrzennego zróżnicowania środowiska zlewni. Umożliwia symulację procesu odpływu ze zlewni z uwzględnieniem: opadu, ewapotranspiracji, intercepcji szaty roślinnej i pokrywy glebowej, infiltracji i podsiąku kapilarnego w glebie oraz odpływu wód podziemnych. Symulowane przebiegi tych procesów zależnione od odpowiednich parametrów skupionych, które były kalibrowane na podstawie danych hydrometeorologicznych, pochodzących $\mathrm{z}$ trzech zlewni rolniczych o zróżnicowanych charakterystykach fizyczno-geograficznych: rzeki Mławka, znajdującej się w dorzeczu Wkry w Polsce Centralnej oraz rzek Kamienna i Sidra, które są dopływami górnej Biebrzy i są zlokalizowane w północno-wschodniej części kraju. Parametry rozłożone zlewni określono na podstawie cyfrowych map gleb, map użytkowania terenu i numerycznego modelu terenu z wykorzystaniem technik GIS. Parametry skupione modelu zostały skalibrowane dla tych trzech zlewni za pomoca zautomatyzowanych technik, opartych na algorytmie PEST. Uzyskane wartości tych parametrów były przedmiotem analizy różnic wynikających z odmiennych charakterystyk zlewni badawczych. Jakość modelu zweryfikowano na materiale zależnym i danych niezależnych. Do oceny jakości modelu wykorzystano odpowiednie miary jakości, między innymi współczynnik sprawności Nasha-Sutcliffe'a. W przypadku dwóch zlewni (Sidry i Kamiennej) uzyskano zadowalającą jakość modelu w zakresie odtwarzania wartości przepływów wysokich, natomiast dla przepływów niskich jakość modelu była niezadowalająca. W przypadku zlewni Mławki odpowiednie wartości miar uzasadniały ocenę jakości modelu jako bardzo dobrą i dobrą. Metodą analizy czułości modelu względem zmian wartości parametrów określono czynniki mające największy wpływ na proces formowania się odpływu rzecznego. Stwierdzono, że ocena jakości modelu w dużym stopniu zależy od jakości danych meteorologicznych i właściwej parametryzacji pokrywy glebowej.

Reviewers:

Prof. Waldemar Mioduszewski

Prof. Antoni T. Miler 